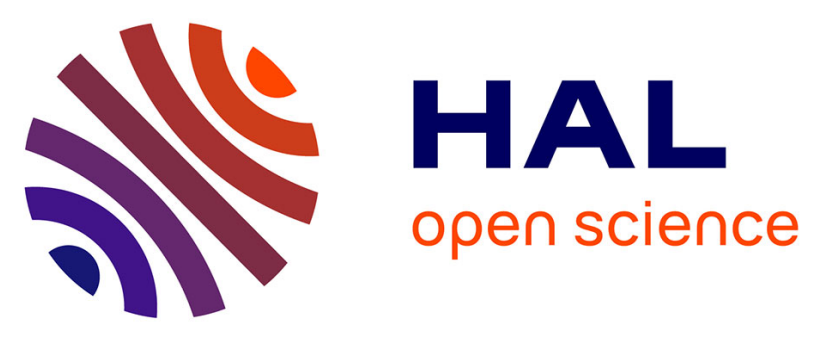

\title{
Diet quality and immunocompetence influence parasite load of roe deer in a fragmented landscape
}

Nora Navarro-Gonzalez, Hélène Verheyden, Hervé Hoste, Bruno Cargnelutti, Bruno Lourtet, Joel Merlet, Simon Boudsocq, Santiago Lavín, A. J. Mark Hewison, Serge Morand, et al.

\section{To cite this version:}

Nora Navarro-Gonzalez, Hélène Verheyden, Hervé Hoste, Bruno Cargnelutti, Bruno Lourtet, et al.. Diet quality and immunocompetence influence parasite load of roe deer in a fragmented landscape. European Journal of Wildlife Research, 2010, 57 (3), pp.639-645. 10.1007/s10344-010-0474-x . hal00649063

\section{HAL Id: hal-00649063 https://hal.science/hal-00649063}

Submitted on 7 Dec 2011

HAL is a multi-disciplinary open access archive for the deposit and dissemination of scientific research documents, whether they are published or not. The documents may come from teaching and research institutions in France or abroad, or from public or private research centers.
L'archive ouverte pluridisciplinaire $\mathbf{H A L}$, est destinée au dépôt et à la diffusion de documents scientifiques de niveau recherche, publiés ou non, émanant des établissements d'enseignement et de recherche français ou étrangers, des laboratoires publics ou privés. 


\title{
Diet quality and immunocompetence influence parasite load of roe deer in a fragmented landscape
}

\author{
Nora Navarro-Gonzalez • Hélène Verheyden • Hervé Hoste • Bruno Cargnelutti • \\ Bruno Lourtet • Joel Merlet • Tanguy Daufresne • Santiago Lavín • \\ A. J. Mark Hewison • Serge Morand • Emmanuel Serrano
}

Received: 8 June 2010 /Revised: 13 November 2010 /Accepted: 17 November 2010/Published online: 7 December 2010

(C) Springer-Verlag 2010

\begin{abstract}
The influence of landscape structure and host diet on parasite load of wildlife is still largely unknown. We studied a roe deer (Capreolus capreolus) population in a fragmented agricultural landscape in southern France to explore the relationship of gastrointestinal nematode load with spleen mass (to index immunocompetence), faecal nitrogen (to index diet quality), landscape structure and age of 33 hunt-harvested roe deer. Gastrointestinal worm counts were negatively related to faecal nitrogen and spleen mass, explaining respectively $24.7 \%$ and $9.2 \%$ of the observed variability in parasite load. Landscape structure did not appear to have a direct influence on gastrointestinal worm counts, but since animals from more open areas have a diet that is richer in nitrogen, its influence may be indirect. In conclusion, in the study area, the colonisation of the agricultural landscape does not seem to have increased the
\end{abstract}

Communicated by C. Gortázar

N. Navarro-Gonzalez $\cdot$ S. Lavín $\cdot$ E. Serrano $(\bowtie)$

Servei d' Ecopatologia de Fauna Salvatge, Departament de

Medicina i Cirurgia Animals, Universitat Autònoma de Barcelona,

E-08193 Bellaterra,

Barcelona, Spain

e-mail: emmanuel.serrano@uab.cat

H. Verheyden • B. Cargnelutti • B. Lourtet · J. Merlet •

T. Daufresne $\cdot$ A. J. M. Hewison

Comportement et Ecologie de la Faune Sauvage,

Institut National de la Recherche Agronomique (INRA),

31326 Castanet-Tolosan Cedex, France

H. Hoste

UMR 1225 Interactions Hôte Agents Pathogènes, INRA/ENVT, 31076 Toulouse Cedex, France

S. Morand

Institut des Sciences de l'Evolution, Université de Montpellier 2, Montpellier, France risk of gastrointestinal nematode parasitism for roe deer, possibly because access to high-quality food enhances immunocompetence.

Keywords Faecal nitrogen - Landscape structure . Ungulate $\cdot$ Spleen $\cdot$ Gastrointestinal nematodes

\section{Introduction}

A key issue in host-parasite ecology is to understand why some individuals are more heavily infected than others (i.e. heterogeneities in parasite infections, sensu Wilson et al. 2002). These heterogeneities may be related to differences in exposure to infective stages of the parasite and/or variations in susceptibility of the host once infected. However, for most host-parasite systems, it is still unclear how the environment, population characteristics and individual variation (i.e. "host-related factors", sensu Alzaga et al. 2009) act and interact to determine observed variation in rates of infection (Michalakis 2009).

In domestic ruminants, host nutrition is a key factor influencing the ability of the host to cope with the negative consequences of parasitism (Coop and Kyriazakis 1999). For example, a combination of poor diet quality (undernutrition) and parasitism contributes to increase the negative (pathological) effects of gastrointestinal parasitism. Furthermore, any improvement in diet quality clearly reduces the establishment and/or persistence of gastrointestinal (GI) nematodes (Coop and Kyriazakis 2001), and may even be considered as an alternative to anthelmintics. However, for populations of free-ranging wild ruminants, the effects of nutritional improvement on parasite load are less clear, since observational (Vicente et al. 2007a) and experimental (Hines et al. 2007) studies have shown that supplementary 
feeding also increases the aggregation of hosts and therefore exposure to some types of parasites (see Gortázar et al. 2006).

Diet quality is related to landscape structure which, under natural conditions, determines the diet composition of sedentary deer (Cornelis et al. 1999; Serrouya and D'Eon 2008). Thus, landscape modifications such as fragmentation can provoke variation in both diet composition and quality, potentially increasing access to high-quality food, and in some cases improving the nutritional status of the host (Miyashita et al. 2007).

On the other hand, landscape modifications may also cause instability in the host-parasite relationship, changing the parasite intensity in a wide range of host species and habitats and modifying the diversity of parasite populations by the capture of parasites from other hosts.

For example, in the midland tropical forest, habitat fragmentation entails a loss of host species richness, increasing the prevalence of haemoparasites in the common fruit bat Artibeus jamaicensis (Cottontail et al. 2009). In a similar way, changes in vegetation cover or the creation of habitat edges can lead to modified survival of parasite infective stages (e.g. helminths of mountain hares, Lepus timidus, Hulbert and Boag 2001). It can also sometimes facilitate encounters with parasites (e.g. acquisition of human gastrointestinal nematodes in primate groups, Chapman et al. 2006). Despite its importance for hostparasite ecology, there is currently little information on the landscape-dependent trade-off between the advantages of improvement in host nutritional status through increasing access to high-quality food against the potential increasement in parasitic risk (Hahn et al. 2003).

The study of interactions between the roe deer and its GI nematodes provides an excellent model to explore this trade-off. This host species, originally considered forest dwelling, relatively recently expanded its range into modern agricultural landscapes (Hewison et al. 2001), thus gaining access to highly nutritious cultivated meadows and crops (Hewison et al. 2009). However, previous work has indicated that human disturbance and restriction in home range has resulted in increased parasite load of this Cervidae (Lutz and Kierdorf 1997). Furthermore, the degree of helminth infestation has been negatively related to both body mass (Segonds-Pichon et al. 1998) and fat reserves (Rossi et al. 1997) and is considered a significant cause of death in roe deer (Aguirre et al. 1999). Indeed, under very high host density these parasites potentially provoke demographic crashes (Maublanc et al. 2009).

In this paper, we analyse variation of parasitic load of roe deer (Capreolus capreolus) living within a fragmented agricultural landscape in South-West France. We focus on gastrointestinal nematodes as a model of parasitism because infection with these helminths, with a simple monoxenic life cycle, directly depends on the feeding behaviour of the host and is markedly influenced by diet quality. We looked for variation in parasite load among individuals in relation to the local level of woodland fragmentation, faecal nitrogen (to index diet quality) and spleen mass (to index immunocompetence). Previous observations in the same area have shown that in the more open sectors of the landscape roe deer form larger winter groups (Hewison et al. 2001) and often feed in agricultural meadows frequented by livestock (personal observation). Hence, since parasite load in wild animals can increase with group size (Ezenwa 2004), contact rate (Gompper and Wright 2005) and exposure to livestock (Zaffaroni et al. 2000), we first hypothesised that parasite load should increase with increasing openness of the local landscape (prediction 1). Better diet quality (Knox et al. 2006) is related to improved immunocompetence (i.e. the overall capacity of a host to mount an immune response against pathogens) and both have been shown to relate to lower GI parasite loads in several species of domestic ruminants (Hoste et al. 2008). In consequence, we also hypothesised that individual roe deer with higher diet quality and higher immunocompetence should exhibit lower parasite loads (prediction 2).

\section{Material and methods}

\section{Study site}

The study area $(10,000 \mathrm{ha})$ is located in the Aurignac canton, South-West France (N $43^{\circ} 13^{\prime}$, E $\left.0^{\circ} 52^{\prime}\right)$, and is a mixed landscape of open fields and remnant woodland. About $33 \%$ of the total area is cultivated, mostly with wheat and barley $(51 \%)$, sunflower $(15 \%)$, maize $(10 \%)$, soya $(5 \%)$, sorghum (8\%) and rape (4\%). Meadows cover about $34 \%$, hedges $7 \%$, woodland patches $14 \%$ and a central forest (630 ha) $7 \%$ of the study area. The human population occurs in small villages and farms connected by an extensive road network. Within this study site, at the scale of a deer's home range, the local landscape structure is spatially variable in terms of the degree of forestation and the type of agricultural activity (see Hewison et al. 2001, 2009 for a more detailed description).

Roe deer data

Roe deer samples $(n=33$, females: 12 adults and 7 yearlings, and males: 11 adults and 3 yearlings) were obtained from legal hunts carried out by local hunting teams during autumn-winter 2006. Hunters recorded the exact location where the deer was harvested on a map immediately after shooting. Within the next few hours, the 
carcass was collected. We converted the precise location of shooting to UTM coordinates, recorded sex and weight (with a spring scale to the nearest $0.1 \mathrm{~kg}$ ) and collected the entire GI tract and head in separate plastic bags. At the laboratory, skulls were boiled in a $1 \%$ potassium hydroxide $(\mathrm{KOH})$ solution and tooth wear was used to assign deer to one of two age classes: yearlings (1.5 years of age), or adults of more than 2 years of age.

\section{Diet quality}

Diet quality was assessed by using the percentage of faecal nitrogen (FN) as an indicator (see Leslie et al. 2008 for a review). The underlying hypothesis is that the relation between FN and diet quality does not change between sites, seasons or individuals. However, tannin, which is often present in browse diets, may alter the relation between FN and diet quality by decreasing protein digestibility and leading to the inflation of tannin bound protein complexes in the faeces (Hobbs 1987; Hudson 1985; Osborn and Ginnett 2001). Roe deer are known to ingest tannins (Clauss et al. 2003; Verheyden-Tixier and Duncan 2000), but assuming that tannin intake is relatively constant between individuals and rather low in winter (Tixier et al. 1997), we expect that FN will still reveal variations of diet quality among individual deer in our study area. For its determination, a sample of faecal pellets was extracted directly from the colon of each tract and stored in a freezer. For subsequent analysis, the faecal pellets were first thawed, ground $(0.5 \mathrm{~mm})$ and oven-dried at $80^{\circ} \mathrm{C}$ for $48 \mathrm{~h}$. Then, total FN content (N\%) was determined with a CN gas analyser (LECO Corporation, St Joseph, MI, USA).

\section{Immnunocompetence}

Spleen mass can be a useful indicator of immunocompetence in mammals that can be easily assessed after death (Corbin et al. 2008). At the laboratory, mesenteries and adhering fat were removed and the spleen dissected and weighed to the nearest $0.1 \mathrm{~g}$ using an electronic digital scale. The possible effect of the blood storage function of this organ on spleen mass was likely similar among individuals, since all animals were shot using drive hunts with dogs, and it is well established that, in response to exercise, the spleen ejects erythrocytes as a compensatory physiological response (Bakovic et al. 2005).

\section{Parasitological methods}

At necropsy, the abomasums and the small and the large intestines of each animal were separated and collected for parasitological analyses. The abomasums and intestines were opened and processed in order to collect the worms from the contents after washings. The number of parasites from the luminal contents of the abomasum and the small intestine were counted based on a $10 \%$ aliquot method.

\section{Landscape description}

In the study area, the annual home range size of roe deer ranges between 17 and 200 ha depending on landscape openness (Cargnelutti et al. 2002). To describe the local landscape structure plausibly used by a given deer, we used a forest index (Hewison et al. 2001). This index is calculated from a raster image (a matrix of $20 \times 20 \mathrm{~m}$ pixels), where each pixel is assigned an arbitrary code value of 200 when it represents woodland, and 0 otherwise. Then, the value of each pixel is replaced by the mean code value of all neighbouring pixels within a certain radius ( $800 \mathrm{~m}$ in this case). Thus, a new matrix is generated with values of pixels ranging from 0 to 200 . This is equivalent to defining the influence of that variable (woodland) within the surrounding environment taking into account the distance between patches of pixels as well as their surface area.

\section{Data analysis}

We performed a set of linear models in which parasite load (i.e. the number of abomasal and intestinal adult worms, as the response variable) was explained by the main effects of age class (two categories: yearlings and adults), sex, forest index, FN and spleen mass and their two-way interactions. Because spleen mass was significantly related to body mass $\left(F_{2,33}=11.318, p\right.$ value $\left.=0.002\right)$, in our analysis we used the residuals from the regression between spleen mass and body mass (constructed for yearlings and adults separately) as a proxy of immunocompetence (corrected spleen mass, hereafter SMc). Then, we performed model selection based on the information-theoretic approach and the Akaike's Information Criterion corrected for small sample sizes (AICc; Burnham and Anderson 2002; Johnson and Omland 2004). Briefly, competing models are ranked in relation to the difference between their Akaike scores with that of the best model $(\Delta i)$, which has the lowest AICc. Models with $\Delta i<2$ units have substantial support for explaining the observed variability in the variable of interest. Subsequently, we estimated the Akaike weight $\left(w_{\mathrm{i}}\right)$, defined as the relative probability that a given model is the best model among those being compared (Burnham and Anderson 2002). Prior to analysis, parasite load, forest index and FN were log-transformed in order to reduce the effect of outliers and to stabilise the relationship between the mean and the variance (Zuur et al. 2007).

Once the best model was selected, we confirmed the general assumptions of linear models (normality and the 
absence of residual pattern in the data). Then, we estimated the degree of collinearity (shared variance) and the percentage of pure variance explained by each parameter included in the selected model by partial linear regression techniques following Zuur et al. (2007). All statistical analyses were performed using $\mathrm{R}$ version 2.12 . 2 (R Development Core Team 2010).

\section{Results}

Our model selection procedure showed that GI parasite load was mainly related to two host-individual factors, the spleen mass and the percentage of FN $\left(w_{\mathrm{i}} \mathrm{SMc}+\mathrm{FN}=0.56, \beta_{\mathrm{SMc}}=\right.$ $\left.-0.015 \pm 0.007, \beta_{\mathrm{FN}}=-18.763 \pm 5.601\right)$. These factors together explained $33.9 \%$ of the observed variability in parasite load of roe deer from the study area (Table 1). However, faecal nitrogen appeared to exert more influence than spleen mass, explaining respectively $24.7 \%$ and $9.2 \%$ of the observed variability in parasite load (Figs. 1 and 2, respectively). On average, deer with low FN (lower than the median value, 3.69) carried $870.6 \pm 235.9$ worms (mean $\pm \mathrm{SE}$ ), while deer with high FN (>3.69) carried much fewer worms (358.8 \pm 88.2). This suggests that roe deer feeding on high-quality diets have lower parasite loads than their counterparts. Similarly, deer with low spleen mass $\left(\mathrm{sMc}_{\mathrm{c}}<105.2\right.$, the median value) carried on average $723.1 \pm 170.0$ worms, while deer with high spleen mass $\left(\mathrm{SM}_{\mathrm{c}}>105.2\right)$ carried a lower parasite load (mean $\pm \mathrm{SE}=532.5 \pm 201.6$ worms).This suggests that higher spleen mass leads to lower parasite load, presumably through

Table 1 Model selection for variation in gastrointestinal parasite load of roe deer $(n=33)$ in a fragmented landscape of South-West France

\begin{tabular}{lllll}
\hline Biological Models & $K$ & AICc & $\Delta i$ & $w_{\mathrm{i}}$ \\
\hline SMc+FN & 4 & 52.75 & 0 & 0.56 \\
FN & 3 & 54.51 & 1.76 & 0.23 \\
$\mathrm{SM}_{\mathrm{c}}+\mathrm{FN}+$ Sex & 5 & 55.37 & 2.62 & 0.12 \\
SMc+FN+Forest Index & 5 & 55.53 & 2.78 & 0.14 \\
Age Class & 3 & 59.32 & 6.57 & $<0.05$ \\
SMc $\times$ Age Class & 5 & 60.09 & 7.34 & $<0.05$ \\
SMc & 3 & 60.63 & 7.89 & $<0.05$ \\
Age Class+Sex & 4 & 61.36 & 8.61 & $<0.05$ \\
$\mathrm{M}_{0}$ & 2 & 61.38 & 8.63 & $<0.05$ \\
Forest Index & 3 & 61.88 & 9.13 & $<0.05$ \\
Forest Index+SMc & 4 & 62.54 & 9.79 & $<0.05$ \\
\hline
\end{tabular}

In bold, models with substantial support. Models with $\Delta i>10$ units are not shown. $S M c$ spleen mass corrected for body mass (yearlings and adults separately), $F N$ faecal nitrogen, $K$ number of parameters including the intercept and error terms, AICc Akaike Information Criterion corrected for small sample size, $\Delta i$ difference of AICc with respect to the best model, $w_{i}$ Akaike weight, $M_{0}$ null model, including only the intercept and the error term

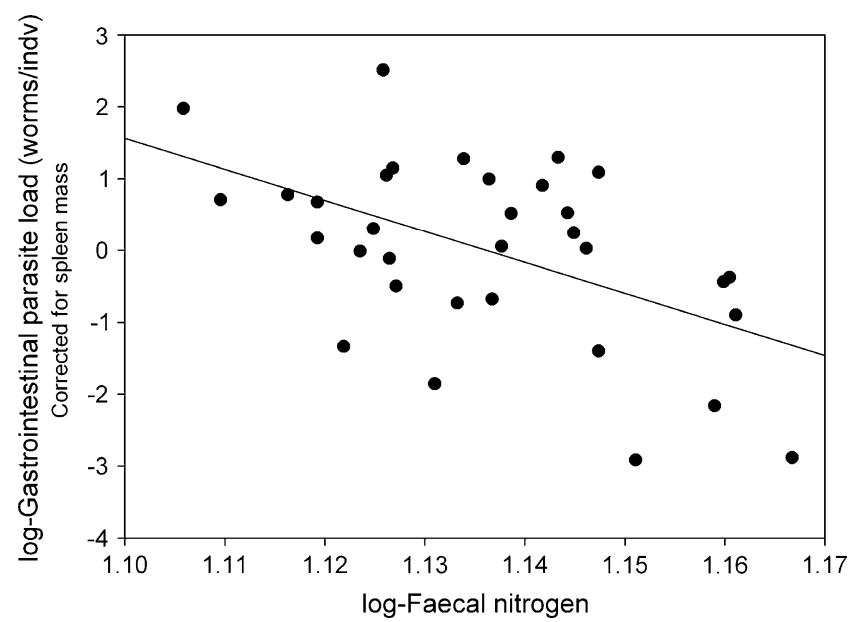

Fig. 1 Relationship between the log-transformed gastrointestinal parasite load corrected for SMc (spleen mass corrected for body weight) and the log-transformed level of faecal nitrogen in yearling and adult roe deer from a fragmented landscape of South-West France

increased immunocompetence. Curiously, the proportion of variance in parasite load explained that was common to both factors was nearly zero $(0.001 \%)$, indicating the lack of any relationship (i.e., collinearity) between the percentage of faecal nitrogen and corrected spleen mass.

In contrast, landscape structure appeared to have little influence on the parasite load of deer, as there was no strong statistical support for the model that included the forest index term $(\Delta i=2.78$; Table 1). Similarly, there was no strong statistical support for including sex in the model ( $\Delta i=2.62)$, indicating similar parasite loads in males and females. Finally, although yearling deer were on average 1.2 times more parasitized than adults (mean $\pm \mathrm{SE}=743 \pm$ 67.90 , vs $550.87 \pm 147.78$ ), there was no strong support for

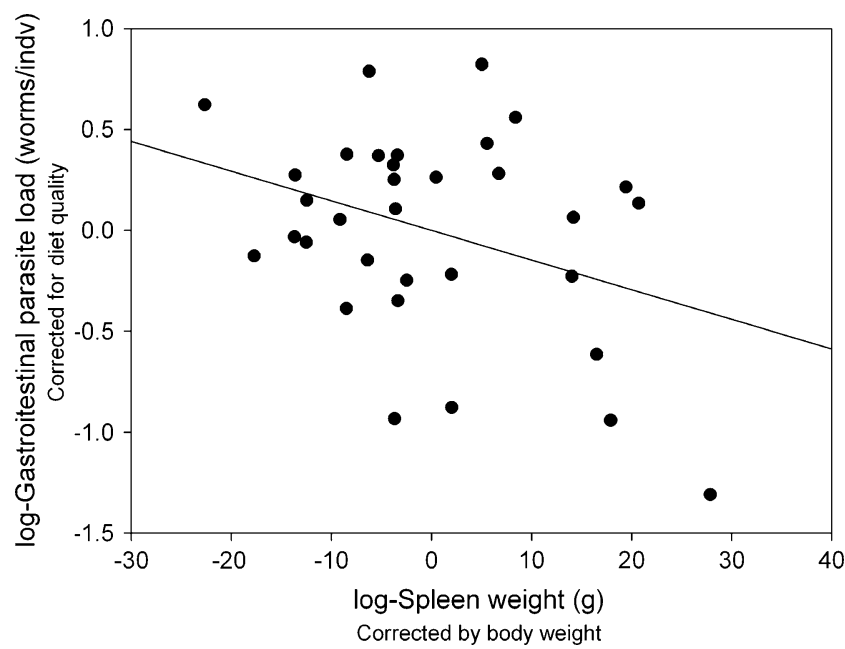

Fig. 2 Relationship between the log-transformed gastrointestinal parasite load corrected for the percentage of faecal nitrogen and the log-transformed spleen mass (corrected for body mass) in yearling and adult roe deer from a fragmented landscape of South-West France 
age-related differences in parasite load in our data set, as the age term was not included in the best models, probably because of the high variability in parasite load within each age class.

\section{Discussion}

Contrary to our first prediction, the local level of woodland fragmentation did not seem to have a marked influence on the GI nematode load of roe deer in our study area, although this result could potentially be due to a lack of power given the rather small sample size available. Instead, in line with our second prediction, both host nutrition (indexed by faecal nitrogen) and immunocompetence (indexed by spleen mass) were the main factors influencing this particular host-parasite system. However, in contrast with previous studies (Rossi et al. 1997), yearlings tended to be more parasitized than adults, although the statistical support for this trend was weak.

The lack of influence of landscape fragmentation on the GI parasite load of roe deer suggests that the parasite risk did not increase with landscape openness (i.e. in the presence of greater host group size and the presence of livestock) in our study site, either because the probability of feeding on plants contaminated with parasite larvae did not increase, and/or because roe deer in more open landscapes are better protected against parasites due to higher immunocompetence or to some diet components with anthelminthic activity (e.g. tannins). Indeed, compared to the forest sector, roe deer density is lower in the more open agricultural areas of our study site (Hewison et al. 2007) which may reduce the likelihood of individual contamination. In addition, livestock are regularly de-wormed and roe deer may avoid pastures with livestock through habitat selection at fine-grained scales. Thus, contrary to our initial prediction on the possible components of the trade-off, the probability of feeding on infected pastures may be lower for roe deer living in open landscapes compared to forest. In addition, roe deer in more open areas appear to be able to obtain higher-quality diets and achieve better body condition by supplementing their feeding with fertilised crops (Hewison et al. 2009), apparently leading to higher resistance to GI nematodes (our results), as has been observed in small ruminants (Hoste et al. 2008). Furthermore, the browsing habits of roe deer (Tixier and Duncan 1996) may reduce the parasitic risk both by minimising the exposition to parasite infective stages lying on the ground and by consuming plants containing secondary compounds with anthelmintic effects, such as tannins, which are generally found in browse (Hoste et al. 2008), as has also been shown in red deer (Hoskin et al. 2000). Indeed, roe deer inhabiting the more open and fragmented areas of the landscape retain strong links to woodland structures (Hewison et al. 2001), using the few remnant woodland patches and hedges (unpublished data) where they may be able to feed on browse with such secondary metabolites with anthelmintic properties.

Spleen mass was related to parasite load, which supports the idea that spleen mass can be considered a reliable proxy of individual immunocompetence notwithstanding other functions of the spleen (see Crivellato et al. 2004). However, it remains difficult to quantify the simple effect of spleen mass on macroparasite load without taking into account the confounding effects of body reserves and condition and their relationship with host nutrition (Coop and Kyriazakis 2001; Vicente et al. 2007b; Serrano et al. 2008). By correcting spleen mass for body mass (a reliable index of condition in roe deer, see Toïgo et al. 2006), we observed significantly lower parasite loads in deer with relatively large spleens (for a given body size), suggesting that spleen size is indeed a reliable indicator of immunocompetence.

Our findings have significant implications for parasite ecology by contributing to a better understanding of the influence of host factors in explaining individual heterogeneities in parasite infection. Further research is needed to better understand the influence of landscape fragmentation on the potential infection risk posed by other kinds of parasites (e.g. microparasites).

Acknowledgements We would like to thank J.P. Chanal and the local hunting associations with the Fédération Départementale des Chasseurs de la Haute Garonne for allowing us to work in the central forest and the surrounding fragmented area respectively. N. NavarroGonzalez was supported by the FPU programme from the Ministerio de Educación, Spain, and E. Serrano by the Juan de la Cierva programme, from the Ministerio de Ciencia e Innovación, Spain. The manuscript was improved by constructive comments of an anonymous reviewer.

\section{References}

Aguirre AA, Brojer C, Mörner T (1999) Descriptive epidemiology of roe deer mortality in Sweden. J Wildl Dis 35:753-762

Alzaga V, Tizzani P, Acevedo P, Ruiz-Fons F, Vicente J, Gortázar C (2009) Deviance partitioning of host factors affecting parasitization in the European brown hare (Lepus europaeus). Naturwissenschaften 96:1157-1168

Bakovic D, Eterovic D, Saratlija-Novakovic Z, Palada I, Valic Z, Bilopavlovic N, Dujic Z (2005) Effect of human splenic contraction on variation in circulating blood cell counts. Clin Exp Pharmacol Physiol 32:944-951

Burnham KP, Anderson DR (2002) Model selection and multimodel inference: a practical information-theoretic approach. SpringerVerlag, New York

Cargnelutti B, Reby D, Desneux L, Angibault JM, Joachim J, Hewison AJM (2002) Space use by roe deer in a fragmented 
landscape some preliminary results. Rev Ecol-Terre Vie 52:2937

Chapman CA, Speirs ML, Gillespie TR, Holland T, Austad KM (2006) Life on the edge: gastrointestinal parasites from the forest edge and interior primate groups. Am J Primatol 68:397-409

Clauss M, Lason K, Gehrke J, Lechner-Doll M, Fickel J, Grune T, Streich WJ (2003) Captive roe deer (Capreolus capreolus) select for low amounts of tannic acid but not quebracho: fluctuation of preferences and potential benefits. Comp Biochem Physiol B 136:369-382

Coop RL, Kyriazakis I (1999) Nutrition-parasite interaction. Vet Parasitol 84:187-204

Coop RL, Kyriazakis I (2001) Influence of host nutrition on the development and consequences of nematode parasitism in ruminants. Trends Parasitol 17:325-330

Corbin E, Vicente J, Martin-Hernando MP, Acevedo P, PérezRodríguez L, Gortázar C (2008) Spleen mass as a measure of immune strength in mammals. Mamm Rev 38:108-115

Cornelis J, Casaer J, Hermy M (1999) Impact of season, habitat and research techniques on diet composition of roe deer (Capreolus capreolus): a review. J Zool 248:195-207

Cottontail VM, Wellinghausen N, Kalko EKV (2009) Habitat fragmentation and haemoparasites in the common fruit bat, Artibeus jamaicensis (Phyllostomidae) in a tropical lowland forest in Panama. Parasitology 136:1133-1145

Crivellato E, Vacca A, Ribatti D (2004) Setting the stage: and anatomist's view of the immune system. Trends Immunol $25: 210-217$

Ezenwa V (2004) Host social behavior and parasitic infection: a multifactorial approach. Behav Ecol 15:446-454

Gompper ME, Wright AN (2005) Altered prevalence of raccoon roundworm (Baylisascaris procyonis) owing to manipulated contact rates of hosts. J Zool 266:215-219

Gortázar C, Acevedo P, Ruiz-Fons F, Vicente J (2006) Disease risks and overabundance of game species. Eur J Wildl Res 52:81-87

Hahn NE, Proulx D, Muruthi PM, Alberts S, Altmann J (2003) Gastrointestinal parasites in free-ranging Kenyan baboons (Papio cynocephalus and $P$. anubis). Int J Primatol 24:271-279

Hewison AJM, Vincent JP, Joachim J, Angibault JM, Cargnelutti B, Cibien C (2001) The effects of woodland fragmentation and human activity on roe deer distribution in agricultural landscapes. Can J Zool 79:679-689

Hewison AJM, Angibault JM, Cargnelutti B, Coulon A, Rames JL, Serrano E, Verheyden H, Morellet N (2007) Using radio-tracking and direct observation to estimate roe deer Capreolus capreolus density in a fragmented landscape: a pilot study. Wildl Biol 13:313-320

Hewison AJM, Morellet N, Verheyden H, Daufresne T, Angibault JM, Cargnelutti B, Merlet J, Picot D, Rames JL, Joachim J, Lourtet B, Serrano E, Bideau E, Cebe N (2009) Landscape fragmentation influences winter body mass of roe deer. Ecography 32:10621070

Hines AM, Ezenwa VO, Cross P, Rogerson JD (2007) Effects of supplemental feeding on gastrointestinal parasite infection in elk (Cervus elaphus): preliminary observations. Vet Parasitol 148:350-355

Hobbs NT (1987) Fecal indices to dietary quality: a critique. J Wildl Manage 51:317-320

Hoskin SO, Wilson PR, Barry TN, Charleston WAG, Waghorn GC (2000) Effect of forage legumes containing condensed tannins on lungworm (Dictyocaulus sp.) and gastrointestinal parasitism in young red deer (Cervus elaphus). Res Vet Sci 68:223-230

Hoste H, Torres-Acosta JFJ, Aguilar-Caballero AJ (2008) Nutritionparasite interactions in goats: is immunoregulation involved in the control of gastrointestinal nematodes? Parasite Immunol 30:79-88
Hudson RJ (1985) Body, energetics and adaptive radiation. In: Hudson RG, White RJ (eds) Bioenergetics of wild herbivores. White. CRC, Boca Raton, pp 1-24

Hulbert IAR, Boag B (2001) The potential role of habitat on intestinal helminths of mountain hares, Lepus timidus. J Helminthol 75:345-349

Johnson JB, Omland KS (2004) Model selection in ecology and evolution. Trends Ecol Evol 19:101-108

Knox MR, Torres-Acosta JFJ, Aguilar-Caballero AJ (2006) Exploiting the effect of dietary supplementation of small ruminants on resilience and resistance against gastrointestinal nematodes. Vet Parasitol 139:385-393

Leslie DM, Bowyer RT, Jenks JA (2008) Facts from feces: nitrogen still measures up as a nutritional index for mammalian herbivores. J Wildl Manage 72:1420-1433

Lutz W, Kierdorf H (1997) Parasitenbelastung von Rehwild (Capreolus capreolus, L) aus benachbarten Revieren mit unterschiedlich starkem Erholungsverkehr. Z Jagdwiss 43:251-258

Maublanc M, Bideau E, Picot D, Rames J, Dubois M, Ferte H, Gerard J (2009) Demographic crash associated with high parasite load in an experimental roe deer (Capreolus capreolus) population. Eur J Wildl Res 55:621-625

Michalakis Y (2009) Parasitism and the evolution of life-history traits. In: Guégan J-F, Renaud F, Thomas F (eds) Ecology and evolution of parasitism. Oxford University Press, Oxford, pp 19-30

Miyashita T, Suzuki M, Takada M, Fujita G, Ochiai K, Asad M (2007) Landscape structure affects food quality of sika deer (Cervus nippon) evidenced by fecal nitrogen levels. Popul Ecol 49:185190

Osborn RG, Ginnett TF (2001) Fecal nitrogen and 2, 6diaminopimelic acid as indices to dietary nitrogen in whitetailed deer. Wildl Soc Bull 29:1131-1139

R Development Core Team 2.12.2 (2010) A language and environment for statistical computing. R Foundation for Statistical Computing, Vienna, Austria. http://www.R-project.org Accessed on $10 / 11 / 2010$

Rossi L, Eckel B, Ferroglio E (1997) A survey of the gastro-intestinal nematodes of roe deer (Capreolus capreolus) in a mountain habitat. Parassitologia (Rome) 39:303-312

Segonds-Pichon A, Ferté H, Fritz H, Gaillard J, Lamarque F, Duncan P (1998) Body mass and parasite load in roe deer (Capreolus capreolus): towards the construction of a new biological indicator of the animal/habitat relationship. Game Wildl Sci 15:397-403

Serrano E, Alpizar-Jara R, Morellet N, Hewison AJM (2008) A half a century of measuring ungulate body condition using indices: is it time for a change? Eur J Wildl Res 54:675-680

Serrouya R, D'Eon RG (2008) The influence of forest cover on mule deer habitat selection, diet, and nutrition during winter in a deepsnow ecosystem. For Ecol Manage 256:452-461

Tixier H, Duncan P (1996) Are European roe deer browsers? A review of variations in the composition of their diets. Rev Ecol-Terre Vie $51: 3-17$

Tixier H, Duncan P, Scehovic J, Yani A, Gleizes M, Lina M (1997) Food selection by European roe deer: effects of plant chemistry, and consequences for the nutritional value of their diets. J Zool 242:229-245

Toïgo C, Gaillard J, Hewison AJM, Morellet N (2006) How does environmental variation influence body mass, body size and body condition? Roe deer is a case study. Ecography 29:301-308

Verheyden-Tixier H, Duncan P (2000) Selection for small amounts of hydrolysable tannins by a concentrate-selecting mammalian herbivore. J Chem Ecol 26:351-358

Vicente J, Höfle U, Fernández-De-Mera IG, Gortázar C (2007a) The importance of parasite life history and host density in predicting the impact of infections in red deer. Oecologia 152:655-664 
Vicente J, Pérez-Rodríguez L, Gortázar C (2007b) Sex, age, spleen size, and kidney fat of red deer relative to infection intensities of the lungworm Elaphostrongylus cervi. Naturwissenschaften 94:581-587

Wilson K, Bjornstad ON, Dobson AP, Merler S, Poglayen G, Randolph SE, Read AF, Skorping A (2002) Heterogeneities in macroparasites infections: patterns and processes. In: Hudson PJ, Rizzoli A, Grenfell BT, Heesterbeek H, Dobson AP (eds) The ecology of wildlife diseases. Oxford University Press, New York, pp 6-44

Zaffaroni E, Manfredi MT, Citterio C, Sala M, Piccolo G, Lanfranchi $\mathrm{P}$ (2000) Host specificity of abomasal nematodes in free ranging alpine ruminants. Vet Parasitol 90:221-230

Zuur AF, Ieno EN, Smith GM (2007) Analysing ecological data. Springer, New York 